\title{
PENGARUH STRES KERJA TERHADAP KINERJA KARYAWAN DI PT PERKEBUNAN NUSANTARA VIII KEBUN TAMBAKSARI
}

\section{Silvy Sondari Gadzali ${ }^{1}$}

Fakultas Ilmu Administrasi Universitas Subang

silvysondari.gadzali@gmail.com

\section{Nurfauziah Lestari ${ }^{2}$}

Fakultas Ilmu Administrasi

nurfauziahlestari14@gmail.com

\section{Muhammad Arif Kurniawan ${ }^{3}$}

Fakultas Ekonomi \& Bisnis Universitas Padjadjaran

kurniawan.arief123@gmail.com

\begin{abstract}
Abstrak
Penelitian ini didasarkan pada potensi Perkebunan Teh yang berada di Kabupaten Subang, PT Perkebunan Nunsatara VIII Kebun Tambaksari merupakan salah satu pekebunan yang ada di Kabupaten Subang. Setiap perusahaan tentu memiliki Target dalam mencapai tujuan yang telah ditentukan. Tidak terealisasinya hasil produksi sesuai dengan target yang diharapkan merupakan salah satu permasalahan yang terjadi di PT Perkebunan Nusantara VIII Kebun Tambaksari. hal ini diduga disebabkan oleh stres kerja yang tinggi. Stres kerja bisa berpengaruh Terhadap Kinerja, tetapi tidak selalu berdampak negatif ketika individu dapat mengelola stres tersebut maka stres kerja akan bernilai positif. Tujuan dalam penelitian ini ingin mengetahui stres kerja dan kinerja yang terjadi di PT Perkebunan Nusantara VIII Kebun Tambaksari, serta ingin mengetahui seberapa besar pengaruh stres kerja terhadap kinerja karaywan PT Perkebunan Nusantara VIII Kebun Tambaksari. Metode yang digunakan dalam penelitian ini berangkat dari titik tolak permasalahan yang terjadi sehingga penelitian ini menggunakan metode kuantitatif,dengan pendekatan survei untuk menjelasakan mengenai pengaruh stres kerja dan kinerja karyawan. serta instrumen penelitian yang digunakan dengan menyebarkan kusioner dengan jumlah respoden sebanyak 73 karyawan Berdasarkan hasil penelitian menunjukan bahwa stres kerja berpengaruh positif dan signifikan terhadap kinerja karyawan PT Perkebunan Nusantara VIII Kebun Tambakasari. Dilihat dari hasil analisis bahwa stres kerja berpengaruh sebesar $30,1 \%$ terhadap kinerja karyawan. Namun pada saat observasi dilakukan bahwa stres kerja bukan merupakan faktor utama yang menyebabkan tidak tercapainya target perusahaan, tetapi iklim kerja yang tidak mendukung dalam proses pekerjaan.
\end{abstract}

Kata kunci : Stres Kerja, Kinerja Karyawan 


\section{Abstract}

This research is based on the potential of tea plantation in Subang Regency, PT Perkebunan Nunsatara VIII Kebun Tambaksari is one of the gardening in Subang Regency. Each company certainly has its Target in achieving a predetermined goal. Unrealized production in accordance with the target is expected one of the problems that occur in PT Perkebunan Nusantara VIII Kebun Tambaksari. This is thought to be caused by high working stress. Working stress can have an effect on performance, but it does not necessarily negatively impact when individuals can manage those stress then work stress will be of positive value. The purpose of this study wants to know the work stress and performance that occurs in PT PerkebunananNusantara VIII KebunTambaksari, and want to know how much impact work stress on the performance of designed PT plantation Nusantara VIII KebunTambaksari. The method used in this research departs from the point of decline of problems that occur so that this research uses quantitative methods, with a survey approach to explain the influence of occupational stress and employee performance. and research instruments used by spreading the questionnaire by a total of 73 respoden. Based on the results of the study showed that the work stress is positive and significant to the performance of employees of PT Plantation Nusantara VIII KebunTambakasari. Judging from the results of the analysis that the work stress affects $30.1 \%$ of employee performance. But at the time of observation is done that work stress is not a major factor that leads to not achieving the target company, but the working climate is not supportive in the job process.

Keywords: Stress work, employee performance

\section{Pendahuluan}

Kinerja merupakan salah satu ukuran atau hasil yang dapat dilihat baik secara individual ataupun institusional. Hal ini menggambarkan bahwa kinerja di dalam suatu perusahaan sangat diperhitungkan. Kinerja karyawan ini mempengaruhi seberapa banyak kontribusi kepada perusahaan. Kinerja yang belum memadai merupakan suatu permasalahan yang sering dihadapi oleh suatu perusahaan dalam usahanya untuk meningkatkan keuntungan yang akan dicapai.

Kinerja merupakan hasil kerja secara kualitas dan kuantitas yang dicapai oleh karyawan dalam melaksanakan tugasnya sesuai dengan tanggung jawab yang diberikan kepadanya (Mangkunegara,2014:9). Kualitas kerja yang dimaksud adalah ukuran seberapa baik seorang karyawan dalam mengerjakan apa yang seharunya ia kerjakan sedangkan kuantitas kerja adalah ukuran seberapa lama seorang karyawan dapat bekerja dalam satu harinya.

Setiap perusahaan membutuhkan karyawan sebagai tenaga yang menjalankan setiap aktivitas yang ada di dalam perusahaan, karyawan memiliki keterlibatan dalam sebuah perencanaan, proses, sistem dan tujuan yang inginkan dalam perusahaan. Seperti yang dikemukakan Rao dalam Indrasari (2017:53) bahwa kekuatan setiap organisasi 
adalah terletak pada orang-orangnya, sehingga dengan demikian kinerja dari organisasi tidak dapat dipisahkan dari kinerja yang telah dicapai oleh seluruh individu dalam organisasi.

PT Perkebunan Nusantara VIII adalah salah satu badan usaha milik negara dibawah holding perkebunan yang menjalankan berbagai perkebunan seperti teh, karet, sawit, sebagai komoditas utama, juga kina, kopi, dan buah-buahan sebagai komoditas penunjang. Kantor pusat PTPN VIII berlokasi di Bandung dan memiliki 41 perkebunan yang tersebar di 11 kabupaten atau kota seluruh provinsi Jawa Barat dan 2 kabupaten di provinsi Banten.

Berdasarkan data yang diperoleh diketahui bahwa realisasi produksi Teh selama 2018 tidak memenuhi target produksi yang ditelah ditetapkan oleh perusahaan, hasil realisasi produksi terendah terjadi pada bulan september dimana total realisasi produksi hanya $107.670 \mathrm{~kg}$ sedangkan target produksi pada bulan tersebut adalah sebesar 211.825 $\mathrm{Kg}$. Realisasi produksi tertinggi terjadi pada bulan Desember yaitu $244.830 \mathrm{Kg}$ sedangkan target produksi pada bulan tersebut adalah sebesar 266.986 bahkan tingkat produksi teh selama 2018 mengalami tingkat fluktuatif. hal ini diduga disebabkan oleh stres kerja yang tinggi.

Stres kerja merupakan suatu keadaan yang timbul dalam interaksi diantara Individu dengan pekerjaan (Beehr \& Newman dalam wijono, 2018:135). bahwa Keadaan yang dimaksud adalah dimana individu mulai menunjukan atau merasakan suatu beban yang dianggap memberatkan bagi individu dengan beberapa gejala yang menunjukan bahwa individu tersebut mengalami stres kerja.

Beberapa gejala yang ditunjukan oleh karyawan setiap afdeling yaitu hilangnya konsentrasi serta mudah lelah ketika sedang bekerja. selain itu karyawan sudah mulai jenuh dengan pekerjaanya. Stres kerja tentu tidak timbul begitu saja, stres kerja dapat timbul karena tuntutan pekerjaan yang tidak seimbang dengan kemampuan.

Kondisi- kondisi yang cenderung mengakibatkan stres dapat ditemukan dalam berbagai situasi pekerjaan dengan reaksi pekerja yang berbeda-beda. Stres pkerja mungkin paling sering dialami kebanyakan karyawan, secara sadar atau tidak itu bisa mempengaruhi kinerja karyawan dalam bekerja. tentunya akan ada dampak yang terjadi ketika seorang karyawan mengalami stres dalam bekerja.

Berdasarkan fenomena-fenomena diatas, terdapat indikator permasalahan yang berkaitan dengan kinerja karyawan di PT Pekerbunan Nusantara VIII kebun Tambaksari yaitu

1. Target Produksi Teh selama 2018 tidak sesuai dengan realisasi.

2. Produksi Teh selama 2018 mengalami tingkat fluktuatif

Keterkaitan antara stres kerja dengan kinerja merupakan aspek penting bagi perusahaan. Salah satu cara untuk meningkatkan kinerja karyawan yaitu dengan memperhatikan stres kerja karyawan. berdasarkan uraian yang dikemukakan diatas, begitu pentingnya mengetahui stres kerja di suatu perusahaan. 


\section{Kerangka Teori}

\section{a.Manajemen Sumber Daya Manusia}

Manajemen secara umum memiliki banyak sudut dan pandang dan persepsi yang berbeda-beda. namun pada umumnya Manajemen merupakan salah satu proses dalam mewujudkan tujuan yang diinginkan dalam perusahaan.

Manajemen yang merupakan ilmu dan seni mengatur proses pemanfaatan sumber daya manusia dan sumber-sumber daya lainya secara efektif dan efesien untuk mencapai tujuan tertentu (Hasibuan, 2012:9). Pada dasarnya sumber daya manusia merupakan suatu sumber daya yang dibutuhkan oleh suatu organisasi, karena sumber daya manusia merupakan sumber daya yang berperan aktif terhadap jalanya suatu organisasi dan proses pengambilan keputusan (Marjuni, 2015:3).

Manajemen sumber daya manusia merupakan ilmu dan seni mengatur hubungan dan peranan tenaga kerja agar efektif dan efesien membantu terwujudnya tujuan perusahaan,karyawan, dan masyarakat (Hasibuan, 2012:10). Manajemen Sumber daya manusia merupakan suatu kebijakan dan praktik yang dibutuhkan seseorang yang menjalankan aspek "orang" atau sumber daya manusia dari posisi manajemen, meliputi perekrutan, penyaringan, pelatihan, pengimbalan, dan penilaian (Dessler dalam Marjino,2015:9)

\section{b. Stress Kerja}

Menurut Priyono (2014:1) Stres merupakan pengalaman subyektif yang didasarkan pada persepsi seseorang terhadap situasi yang dihadapinya. Sunyoto dalam Riandy (2016:1063) menyatakan bahwa stres merupakan konsekuensi setiap tindakan dan situasi lingkungan yang menimbulkan tuntutan pisikologis dan fisik yang berlebihan pada seseorang. Stres bisa terjadi didalam lingkungan kerja maupun diluar lingkungan kerja. Stres yang dialami didalam lingkungan kerja yaitu stres yang dihadapi oleh karyawan yang terjadi di dalam organisasi atau perusahaan misalnya desakan waktu, tekanan \& beban kerja yang berlebihan. Sedangkan stres yang dialami diluar lingkungan kerja yaitu stres yang dihadapi karyawan yang terjadi diluar organisasi atau perusahaan tetapi tetap berpengaruh pada diri karyawan, misalnya masalah keluarga, pernikahan, keuangan, kesehatan, dan masalah-masalah pribadi lainnya.

Mangkunegara (2011:157) menyatakan, stres kerja merupakan perasaan tertekan yang dialami karyawan dalam menghadapi pekerjaan. Sedangkan Menurut Robbins (2006:793) Stres kerja merupakan kondisi yang muncul dari interaksi antara manusia dan pekerjaan serta dikarakteristikan oleh perubahan manusia yang memaksa mereka untuk menyimpang dari fungsi normal mereka.

Menurut Beehr \& Newman dalam Wijono (2018:145). Stres kerja merupakan suatu keadaan yang timbul dalam interaksi diantara Individu dan pekerjaan. Keadaan yang dimaksud adalah dimana individu mulai menunjukan atau merasakan suatu beban yang dianggap memberatkan bagi individu dengan beberapa gejala yang menunjukan bahwa individu tersebut mengalami stres kerja. 
Dimensi dan indikator yang digunakan Menurut Robbins dalam Asih (2015:47) dimana dimensi tersebut yaitu external dan internal dari yang bersangkutan dapat mempengaruhi reaksi emosional dan psikologis yang terjadi pada situasi dimana tujuan individu mendapat halangan dan tidak dapat mengatasinya

\section{b.1. Dimensi stres kerja}

Dua dimensi stress kerja Robbins dalam Asih (2015:47) antara lain :

a) Aspek eksternal merupakan suatu kondisi yang mempengaruhi psikologis seseorang yang berasal dari luar dirinya adapun indikatornya

1. Beban kerja

2. Waktu kerja

3. Karakteristik tugas

4. dengan rekan kerja dan pimpinan

5. Dukungan sarana dan prasarana

b) Aspek internal dengan indikator merupakan suatu kondisi yang disebabkan oleh adanya konflik atau hambatan yang terjadi dalam diri seseorang dan tidak mampun untuk mengendalikannya.

1. Konflik kerja

2. Kemajuan karir dan diri

\section{c. Kinerja Karyawan}

Kinerja berhubungan erat dengan pencapaian tujuan perusahaan, karena karyawan merupakan salah satu faktor utama bagi perusahaan dalam mencapai tujuan yang telah ditetapkan. Menurut Kusriyanto, dalam Mangkunegara (2014:9) Kinerja karyawan merupakan perbandingan hasil yang dicapai dengan peran serta tenaga kerja persatuan (waktu lazimnya perjam).

Menurut Bastian, dalam Fahmi (2015:2) kinerja merupakan gambaran mengenai tingkat pencapaian pelaksanaan suatu kegiatan/program/kebijaksanaan dalam mewujudkan sasaran, tujuan, misi, dan visi organisasi yang tertuang dalam perumusan skema strategis (startegic Planning) suatu organisasi.

Menurut A.A. Anwar Prabu Mangkunegara (2014:9) Kinerja karyawan merupakan hasil kerja secara kualitas dan kuantitas yang dicapai oleh seorang karyawan dalam melaksanakan tugasnya sesuai dengan tanggung jawab yang diberikan kepadanya. Adapun yang dimaksud dengan kualitas kerja adalah ukuran seberapa baik seorang karyawan dalam mengerjakan apa yang seharunya ia kerjakan sedangkan kuantitas kerja adalah ukuran seberapa lama seorang karyawan dapat bekerja dalam satu harinya.

\section{c.1. Dimensi Kinerja Karyawan}

Mathis dalam Filanisa (2017:19) menjelaskan dimensi kinerja karyawan sebagai hasil pekerjaan yang dicapai karyawan berdasarkan dimensi kerja, berikut dimensi serta indikatornya :

a. Kualitas hasil kerja 
Hasil Kerja yang dicapai oleh pegawai yang sesuai dengan syarat-syarat ketentuan dari perusahaan. Indikatornya adalah ketelitian hasil kerja.

b. Kuantitas hasil kerja

Jumlah hasil kerja yang diselesaikan oleh pegawai. Indikatornya adalah hasil pencapaian kerja

c. ketepatan waktu

Ketepatan waktu sesuai dengan standar yang dicapai pegawai dalam menyelesaikan pekerjaan yang telah diberikan perusahaan. Indikatornya adalah kecepatan waktu dalam bekerja.

d. Kehadiran

Karyawan memenuhi atau tidaknya standar nilai kehadiran sesuai dengan aturan atau tata tertib yang berlaku dalam organisasi, Indikatornya adalah pencapaian kehadiran.

e. Dampak Interpersonal

Hasil hubungan karyawan dalam saat bekerja sama, Komunikasi, \& peran serta dalam perusahaan. Indikatornya adalah bekerja sama, komunikasi, dan peran serta.

Salah satu cara yang dapat digunakan untuk melihat perkembangan perusahaan adalah dengan cara melihat hasil penilaian kinerja. Penilaian kinerja merupakan suatu penilaian yang dilakukan pihak manajemn perusahaan baik para karyawan maupun manajer yang selama ini telah melakukan pekerjaanya (Fahmi, 2015:65).

Suatu perusahaan perlu melakukan penilaian kinerja untuk mengningkatkan kualitas kinerja perusahaan. Seperti yang dikemukakan Griffin dalam Fahmi (2015:67) bahwa kinerja karyawan seharusnya dievaluasi secara berkala karena berbagai alasan. Untuk melakukan kinerja dibutuhkan metode penilian yang memiliki tingkat dan analisa yang representatif.

Dua kategori dasar dari metode penilaian yang sering digunakan dalam organiasi yaitu

a. Metode objektif merupakan metode yang menyangkut sejauh mana seseorang bisa bekerja dan menunjukan bukti kemampuan ia bekerja sesuai dengan kemampuan yang dimilikinya.

b. Metode pertimbangan adalah metode penilaian berdasarkan nilai rangking yang dimiliki seseorang karyawan, jika ia memiliki nilai rangking yang tinggi maka artinya ia memiliki kualitas kerja yang bagus dan begitu pula sebaliknya.

\section{d. Pengaruh Stres kerja terhadap Kinerja Karyawan}

Stres kerja mungkin salah satu yang tidak bisa dihadari, setiap karyawan pasti mengalami stres dalam bekerja, secara sadar atau tidak itu bisa mempengaruhi kinerja karyawan dalam bekerja. Keterkaitan antara stres kerja terhadap kinerja, hukum Yerkses - Dodson merupakan hubungan empiris antara gairah atau tekanan yang dialami oleh seseorang (stres) dengan kinerja, awalnya dikembangkan oleh psikolog Robert M. Yerkes dan Johon Dillingham Dodson

Menurut Yarkes - Dodson dalam Ardi (2017 : 4) mengemukakan teori bahwa ketika stres yang dihadapi oleh seseorang meningkat, maka tingkat kinerja yang 
dihasilkan juga ikut meningkat, namun ketika stres yang dialami melebihi kapasitas individu tersebut dalam menghadapainya maka akan berpengaruh negatif terhadap kinerja.

Hal ini sesuai dengan yang dikemukakan oleh Wartono \& Mochtar (2015:170) bahwa Stres tentu akan berpengaruh pada kinerja seseorang (pekerja) tetapi tidak selamanya stres akan merugikan individu atau perusahaan. Dengan memahami faktor penyebab dan mengelolanya dengan baik maka stres dalam tingkatan tertentu bahkan bisa menghasilkan ide-ide kreatif sehingga akan menghasilkan dampak positif bagi individu maupun perusahaan dalam bekerja.

\section{Metode Penelitian}

Penelitian ini menggunakan metode kuantitatif, dimana lebih menitikberatkan pada aspek pengukuran secara obyektif sehingga penelitian ini berangkat dari masalah yang menjadi titik tolak dari penelitian yang sudah jelas data-datanya. Jenis Penelitian menggunakan penelitian Eksplanasi, untuk menjelaskan suatu generalisasi sampel terhadap populasinya atau menjelaskan hubungan, perbedaan, pengaruh satu variabel dengan variabel lainnya (Bungin,2005:46).

Pendekatan survei, digunakan untuk menjelaskan pengaruh antara dua variabel atau lebih melalui pengujian hipotesis, survei dilakukan dengan cara mengambil populasi dengan menggunakan kuesioner sebagai alat pengumpulan data.

Populasi dalam penelitian ini adalah karyawan PT yang tercatat adalah 484 orang. Menurut Urika (2016: 61) Sejauh ini tidak ada ketentuan atau peraturan yang menetapkan berapa jumlah yang harus diambil agar dianggap dapat mewakili populasi. PT Perkebunanan Nusantara VIII Kebun Tambaksari ini memiliki 2 Komoditi yaitu Teh dan Sawit, namun dikarenakan peneliti memilih Permasalahan yang terjadi di komoditi teh maka sampel yang dipilih adalah karyawan tetap yang bekerja di 3 afdeling yaitu kasomalang, Tambaksari, dan Bukanagara.

Teknik pengambilan sampel yang digunakan dalam penelitian ini adalah sampel propabilitas yang merupakan teknik pengambilan sampel yang memberikan peluang yang sama bagi setiap unsur anggota populasi untuk dipilih sebagai anggota sampel penelitian. Penelitian ini juga menggunakan teknik cluster sampling dimana teknik pengambilan sampel yang mengacu pada kelompok bukan pada individu. Yang termasuk sebagai anggota sampel adalah anggota yang berada dalam kelompok terpilih itu, sehingga sampel dalam penelitian ini sebesar 73 responden, dimana responden dalam penelitian ini merupakan karyawan tetap dari afdeling kasomalang, Tambaksari dan Bukanagara.

\section{Hasil dan Pembahasan}

Karaktersistik responden merupakan salah satu informasi yang diperlukan untuk mengetahui identitas responden. Informasi yang diberikan responden dalam penelitian ini mengenai identitas diri mulai dari jenis kelamin, usia, pendidikan dan masa kerja. Responden dalam penelitian yaitu karyawan tetap afdeling Kasomalang, Tambaksari, dan Bukanagara yang berjumlah 73 orang. yang dapat diuraikan sebagai berikut : 


\section{Jenis Kelamin}

Berdasarkan hasil pernyebaran kuesioner karakterisitik responden berdasarkan jenis kelamin dalam penelitian ini dapat dilihat pada grafik 4.1 sebagai berikut Karakteristik Responden Beradasarkan Jenis Kelamin

\section{Diagram 4.1}

Karakteristik responden berdasarkan jenis kelamin

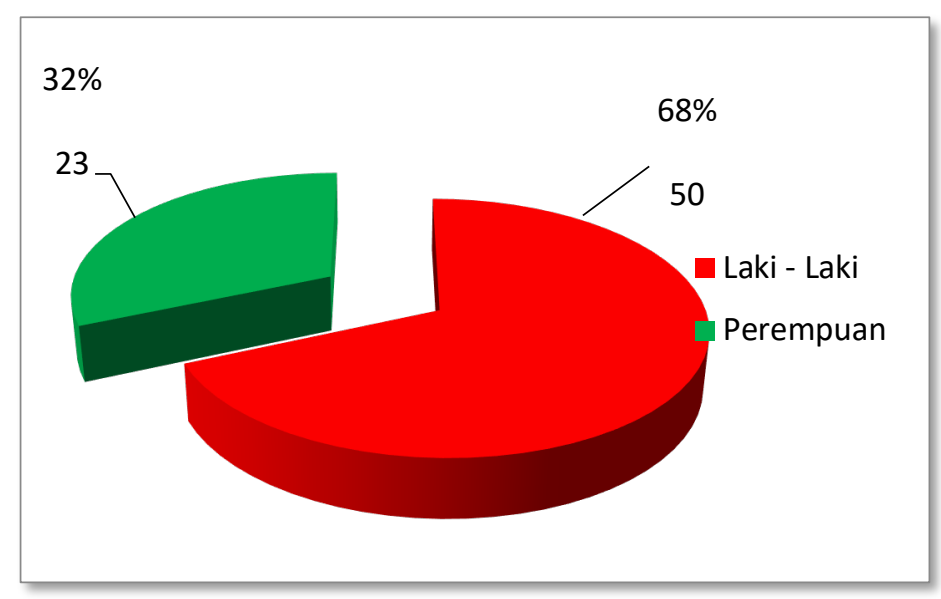

Dalam penelitian ini responden sebanyak 68\% merupakan responden berjenis kelamin laki -laki dan $32 \%$ perempuan. Sehingga sampel terbanyak adalah responden laki - laki yaitu 50 responden.

\section{Usia}

Usia merupakan Salah satu faktor yang dapat berpengaruh terhadap kinerja seseorang atau karyawan, semakin lanjut usia seseorang akan mempengaruhi kinerja hal ini bisa dilihat dalam ketelitian, konsentrasi serta ketahanan fisik dalam bekerja. Data yang diperoleh dapat dilihat dalam Diagram 4.2 di bawah ini, 


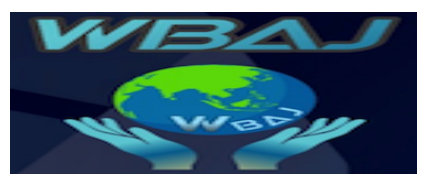

Volume 2 Issue 1, Juni 2020

\section{Diagram 4.2}

Karakteristik responden berdasarkan tingkat usia

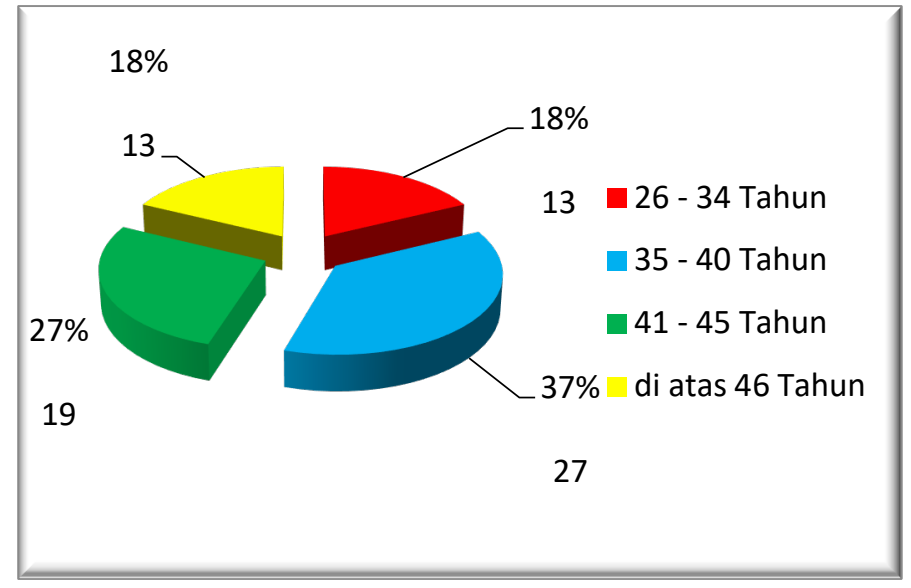

Grafik 4.2. bahwa pengelompokan usia responden yang paling banyak berusia 35 - 40 tahun (37\%) sedangkan yang paling sedikit berusia $26-34$ Tahun (18\%). Usia produktif dalam bekerja ada pada usia 35 - 40 Tahun, berdasarkan jawaban responden bahwa Mayoritas usia karyawan PT Perkebunan Nusantara VIII Kebun Tambaksari merupakan 35 - 40 sehingga karyawan memiliki usia produktif dalam bekerja.

\section{Pendidikan}

Identitas responden berdasarkan tingkat pendidikan hal ini didasari bahwa setiap karyawan memiliki tingkat pendidikan yang berbeda-beda, hal ini bisa dilihat dalam Diagram 4.3 di bawah ini,

\section{Diagram 4.3}

Karakteristik responden berdasarkan pendidikan terakhir

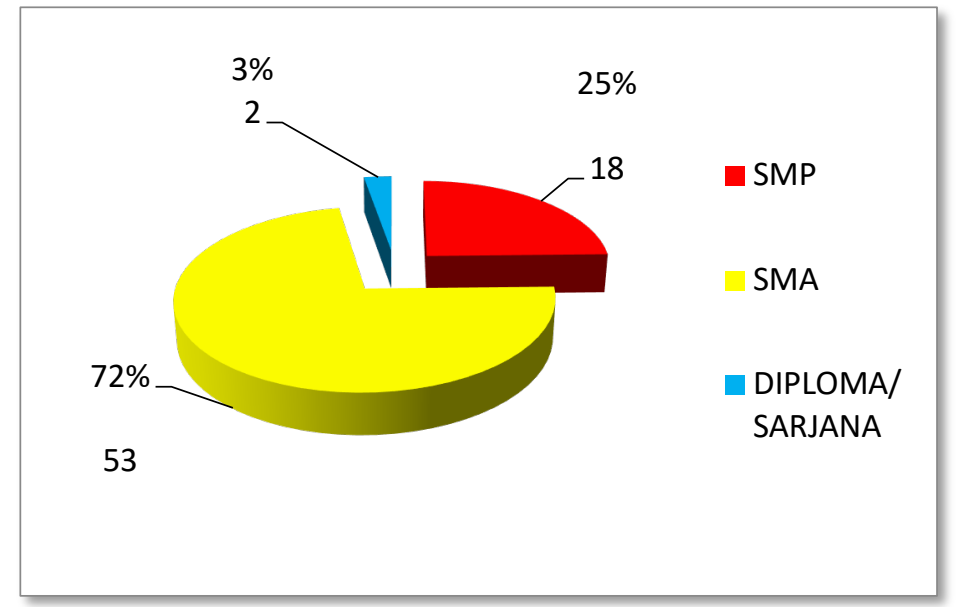




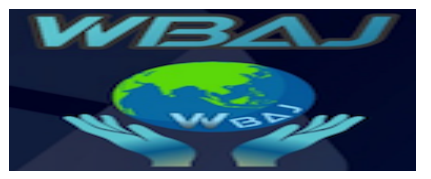

Volume 2 Issue 1, Juni 2020

https://ejournal.unsub.ac.id/index.php/bisnis

Tingkat pendidikan responden sebanyak 72\% merupakan berpendidikan SMA, $25 \%$ berpendidikan SMP dan $2 \%$ berpendidikan Diploma/ sarjana.

Tingkat pendidikan memang menentukan sikap dan tindakan seseorang dalam melakukan kegiatan atau pekerjaan yang dijalaninya. Semakin tinggi tingkat pendidikan seseorang maka semakin cepat pula seseorang mengerti atau memahami suatu kondisi dan pekerjaan yang dilimpahkan kepadanya dengan tingginya tingkat pendidikan ini maka perusahaan berharap karyawan dapat memberikan kinerja yang baik dan bermutu.

\section{Masa Bekerja}

Masa bekerja merupakan salah cara untuk mengetahui secara mendalam mengenai masa bekerja para Karyawan tetapdi PT. Perkebunan Nusantara VIII Kebun Tambaksari terutama pada karyawan afdeling kasomalang, Tambaksari, dan Bukanagara.

Diagram 4.4

Karakteristik responden berdasarkan masa bekerja

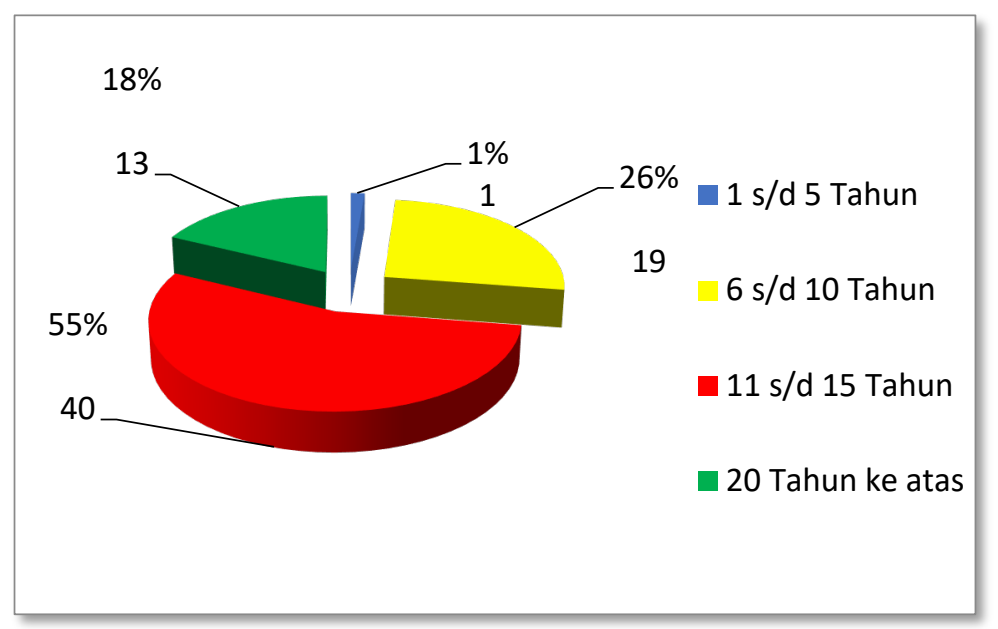

Mayoritas responden yang telah bekerja di PT Perkebunana Nusantara VIII Kebun Tambaksari yaitu 40 atau 55\% responden telah bekerja selama $11 \mathrm{~s} / \mathrm{d} 15$. Hal ini menunjukan bahwa karyawan PT Perkebunan Nusantara VIII Kebun Tambakari merupakan karyawan yang sudah berpengalaman sehingga masih sangat memungkinan untuk meningkatkan kinerjanya.

\section{Stress Kerja}

\section{A. Beban Kerja}

Untuk beban kerja menunjukan bahwa sebanyak 44 orang atau $60 \%$ menjawab ragu-ragu, namun 26 atau 36\% menjawab setuju dan 3 atau 4 responden tidak setuju 
mengenai pernyataan terkait memiliki kemampuan yang baik dalam menyelesaikan beban pekerjaan yang diberikan oleh perusahaan. Mayoritas Responden menjawab raguragu memiliki kemampuan yang baik dalam menyelesaikan beban kerja yang diberikan perusahaan, Menurut Robbins (2008:173) bahwa Positif dan Negatif beban kerja merupakan masalah persepsi. tentu Karyawan memiliki penilaian sendiri mengenai beban kerja yang diberikan oleh perusahaan.

Hal ini tergantung dari bagaimana karyawan meilihat beban kerja yang diberikan perusahaan, sehingga mayoritas jawaban responden menjawab ragu-ragu. Setiap Karyawan memiliki kemampuan yang berbeda-beda dalam melaksanakan tugasnya, hal ini terlihat dari jawaban responden bahwa 26 responden menjawab setuju. karyawan merasa memiliki kemampuan yang baik dalam menyelesaikan beban kerja yang diberikan oleh perusahaan

Menurut Umawas dkk (2018:21) bahwa kemampuan pekerja lebih tinggi dari tuntutan pekerjaan, maka akan muncul perasaan bosan, namun sebaliknya jika kemampuan pekerjaan lebih rendah daripada tuntutan pekerjaan, maka akan muncul kelelahan yang lebih. Kemampuan karyawan dalam menyelesaikan beban kerja yang diberikan perusahaan tergantung dari persepsi tentang bagaimana melihat pekerjaanya, ketika karyawan merasa tidak memiliki kemampuan yang baik dalam menyelesaikan beban kerja atau tuntutan pekerjaan, maka akan muncul kelelahan yang lebih sehingga hal ini bisa mempengaruhi kinerja dari karyawanya.

\section{B. Waktu Kerja}

Hasil penelitian menunjukan bahwa sebanyak 39 orang atau 53\% menjawab setuju Namun bagi 19 responden menjawab ragu-ragu sedangkan bagi 13 responden menjawab tidak setuju dan 2 orang menjawab sangat tidak setuju. Hasil Tanggapan responden mengenai waktu kerja memang berbeda-beda. Hal ini berkaitan dengan waktu penyelesaian pekerjaan yang diselesaikan setiap afdeling berbeda-beda baik itu Kasomalang, Bukanagara, dan Tambaksari.

Kondisi dan situasi dilapangan memang sulit untuk diprediksi sedangkan setiap karyawan memiliki target setiap harinya untuk menyelesaikan pekerjaanya. Tentu bagian kantor menunggu hasil laporan dari lapangan sehingga seringkali pekerjaan yang dihadapinya melebihi jumlah jam kerja.

Ketika pekerjaan belum selesai tapi waktu kerja telah selesai, terkadang karyawan sudah mulai tidak berkonsentrasi dalam bekerja sehingga pekerjaan menjadi salah atau pekerjaan kadang dibawa kerumah. Hal ini sesuai dengan yang dikemukakan oleh Harrington dalam Trinugroho (2017:77) menyatakan bahwa lamanya jam kerja waktu berlebih dapat meningkatkan humaneror atau kesalahan kerja karena kelelahan yang meningkat dan jam tidur yang berkurang. Agar pekerjaan yang dilakukan tidak menghambat pekerjaan lain serta terhindar dari kesalahan, oleh karena itu karyawan harus dapat memanfaatkan waktu sebaik mungkin pada saat kondisi dan situasi tidak mendukung, sehingga pekerjaan dapat diselesaikan sesuai dengan waktu yang telah ditentukan oleh perusahaan. 


\section{Karakteristik Tugas}

Hasil penelitian menunjukkan sebanyak 37 atau $51 \%$ responden menjawab setuju, 31 atau $42 \%$ responden menjawab tidak setuju dan 5 atau $7 \%$ menjawab sangat tidak setuju atas item pernyataan berkaitan dengan Karakteristik Tugas.

Mayoritas Responden menjawab Setuju mengenai karaktersitik tugas, responden mengetahui apa yang menjadi tugasnya dan merasa bahwa tugas yang diberikan perusahaan sesuai dengan kemampuanya. Hal ini sesuai dengan yang dikemukakan oleh Ananda dan Suharyono (2018:73) bahwa Karyawan yang mengetahui semua detail tugas dari perkerjaan yang dijalani, merasa dirinya mampu melaksanakan setiap pekerjaan maupun tanggung jawab yang diberikan serta mengetahui berbagai macam hal yang berhubungan dengan karakteristik pekerjaanya.

Namun tidak semua responden menjawab setuju memiliki kemampuan yang baik dalam menyelesaikan pekerjaanya, hal ini karena karyawan merasa tugasnya tidak sesuai dengan kemampuanya, sehingga karyawan merasa bingung pada saat melaksanakan pekerjaanya. Akhrinya karyawan merasakan stres bahwa pekerjaanya tidak sesuai dengan kemampuanya.

Hal ini sesuai dengan apa yang dikemukakan oleh Tosi dalam Wijono (2010:154) bahwa kemampuan merupakan salah satu aspek yang dapat mempengaruhi respon-respon invidividu terhadap kondisi, situasi, atau peristiwa yang akhirnya menimbulkan stres.

Stres timbul memang tidak bergitu saja tentu ada penyebab kenapa setiap individu dapat mengalami stres dalam bekerja. Hal ini sesuai dengan yang dikemukakan oleh Sopiah dalam Wijaya (2017:285) bahwa salah satu penyebab stres karena perantugas termasuk kondisi dimana para pegawai mengalami kesulitan dalam memahami apa yang menjadi tugasnya.

D. Hubungan Dengan Rekan Kerja

Hasil penelitian menunjukan sebanyak 43 orang atau 59\% responden menjawab setuju, Namun bagi 26 responden atau 36\% menjawab tidak setuju sedangkan 4 responden atau 5\% menjawab sangat tidak setuju. Mayoritas responden menjawab setuju atas pernyataan memiliki hubungan yang baik dengan rekan kerja dan atasan. Menjalin hubungan yang baik dengan rekan kerja dan atasan dapat memudah dalam bekerja. Hal ini sesuai dengan yang dikemukakan oleh Oktavianda dan Iqbal (2018:108) Didalam perusahaan atasan dan bawahan harus berhubungan baik untuk mengoptimalkan sumber daya manusia yang ada, selain itu agar target perusahaan tercapai dengan efektif serta menciptakan keunggulan bersaing. Dapat dikatakan menjalin hubungan baik dalam Karyawan tentu akan menjaga hubungan dengan rekan kerja dan atasan hal ini dapat memudahkan dalam proses pelaksanaan pekerjaan, memang tidak bisa dipungkiri bahwa terkadang urusan pribadi sering dibawa kedalam hubungan pekerjaan.

\section{E. Dukungan Sarana dan Prasarana}

Mayoritas responden sebanyak 40 atau 55\% menjawab Tidak setuju dan 16 atau $22 \%$ responden menjawab sangat tidak setuju mengenai pernyataan Dukungan Sarana dan Prasarana. Namun bagi 17 responden atau 23\% menjawab setuju bahwa penyediaan sarana dan prasarana cukup untuk memudahkan dalam melaksanakan pekerjaan. 
Berdasarkan hasil observasi bahwa salah satu kendala dalam proses pekerjaan yaitu sering kali mesin petik rusak. Sehingga menghambat dalam proses pekerjaan. Tentunya mandor dan pemetik setiap harinya memiliki target yang harus dicapai namun sarana yang digunakan belum memudahkan dalam proses pekerjaan.

Seperti dikemukakan oleh Filanisa (2017:21) bahwa Penyediaan sarana dan prasarana mempengaruhi kinerja seseorang, penggunaan peralatan dan teknologi maju saat ini bukan saja dimaskud untuk meningkatkan kinerja akan tetapi dipandang untuk memberikan kemudahaan dan kenyamaan kerja.

Perusahaan tentu perlu lebih memperhatikan kondisi sarana dan prasarana yang ada. Apakah berfungsi dengan optimal, perlu perbaikan atau perlu diganti. Sehingga karyawan dapat bekerja dangan optimal. tentu untuk mencapai target banyak faktor yang harus diperhatikan Salah satunya dengan memperhatikan sarana dan prasarana yang ada di tempat kerja. tentu tersedianya sarana dan prasarana yang memadai sangat menunjang kinerja karyawan.

\section{F. Konflik Kerja}

Hasil menunjukan bahwa mayoritas responden sebanyak 49 orang atau $67 \%$ menjawab Ragu-ragu atas item peryataan yang berkaitan dengan konflik. Namun bagi 15 responden atau 21\% menjawab sangat tidak setuju Mayoritas responden menjawab ragu-ragu berkaitan dengan konflik kerja, Konflik yang terjadi biasanya kurangnya komunikasi dalam bekerja serta perbedaan pendapat mengenai pekerjaan. Hal ini sesuai dengan yang dikemukakan oleh Robbins dan Judge (2008:173) bahwa konflik merupakan suatu proses yang dimulai ketika satu pihak memiliki persepsi bahwa pihak lain akan atau telah mempengaruhi secara negatif, sesuatu yg menjadi kepedulian atau kepentingan pihak pertama. Hadirnya konflik memang tergantung dari bagaimana individu tersebut menilai sesuatu sebagai konflik atau tidak. Setiap orang mempunyai cara tersendiri dalam menangapi hal teserbut. Tidak bisa dipungkiri bahwa konflik akan selalu hadir hal ini karena perbedaan pendapat, pandangan atau persepsi yang akhirnya terkadang malah menimbulkan konflik, tentu jika terjadi konflik yang berkelanjutan akan membuat stres sehingga akan menggangu dalam bekerja.

\section{G. Kemajuan diri dan karier}

Hasil penelitian menunjukan bahwa responden sebanyak 37 atau $51 \%$ menjawab ragu-ragu, 21 atau 29\% responden menjawab sangat setuju, 14 atau 19\% responden menjawab tidak setuju,dan 1 atau $1 \%$ repoden menjawab sangat tidak setuju bahwa meraka merasa mengalami peningkatan karier dalam bekerja di perusahaan ini.

Karier merupakan sarana yang memiliki kesempatan untuk membentuk seseorang membuat perencanaan kariernya dengan mempertemukan antara keahlian, keinginan, dan tujuannya dengan kebutuhan dan tujuan perusahaan (Masram dan Mu'ah,2017:182). Karyawan selalu mengharapakan bahwa kariernya akan meningkat, perusahaan tentu akan memberikan peningkatan karier namun secara bertahap hal ini karena perusahaan perlu memperhatikan latar belakang pendidikan, proses dalam menjalankan tugasnya serta kemampuan yang dimilikinya. 


\section{Kinerja Karyawan}

\section{A. Kualitas Kerja}

Berdasarkan hasil observasi ketelitian memang diperlukan oleh setiap karyawan, salah satunya mandor dan pemetik, untuk mendapatkan kualitas Teh yang baik, tentu perlu diperhatikan bagaimana proses pada saat memetik Teh. Hal ini karena Pucuk merupakan salah satu bahan yang digunakan dalam proses pengelolahaan Teh menjadi Teh jadi selain itu Pucuk merupakan salah satu tanaman yang paling sensitif, sehingga keteletian karyawan sangat diperlukan.

Selain itu karyawan bagian kantor pun harus teliti berkaitan dengan laporan yang harus dibuat setiap harinya, karena setiap laporan harus langsung dikirm pusat, sehingga karyawan harus teliti dalam mengerjakan perkerjaanya masing-masing. ketika waktu pulang telah tiba sedangkan pekerjaan belum selesai terkadang membuat konsentrasi menjadi kacau dan akhirnya terkadang pekerjaan banyak yang salah.

Kualitas hasil kerja tergantung bagaimana karyawan dalam mengerjakan tugasnya, Ketelitian memang merupakan salah satu yang harus dilakukan dalam proses bekerja, untuk menghasilkan produk Teh yang berkualitas tentu banyak hal yang harus dipersiapkan. Salah satunya dengan memperhatikan proses dalam memetik Teh. Serta proses mengerjakan laporan hal ini berarti Karyawan tentu harus melakukanya dengan baik dan sesuai dengan prosedur

\section{B. Kuantitas Kerja}

Hasil kerja Karyawan bagian lapangan memang berkaitan Kondisi dan situasi dilapangan, iklim yang terkadang tidak mendukung dalam proses pelaksanaan pekerjaan membuat target yang telah ditentukan oleh perusahaan tidak sesuai dengan realisasinya. Selain itu Karyawan juga harus dapat memanfaatkan hasil ketika iklim sedang mendukung dalam proses pencapaian tujuan, Dengan begitu perusahaan tentu mengharapakan bahwa karyawan dapat menghasilkan kuantitas yang sesuai dengan harapan perusahaan.

\section{Ketepatan waktu}

Setiap bentuk laporan setiap harinya harus menunggu hasil dari lapangan. Terutama berkaitan dengan laporan hasil dari lapangan. tentu Setiap karyawan tidak bisa menunda-nunda pekerjaan. karena akan menghambat dalam prosess pekerjaan, untuk itu setiap karyawan harus memahami apa yang menjadi tugasnya untuk memudahkan rekan kerja yang lain agar pekerjaanya sama-sama selesai. Dapat dikatakan bahwa kondisi dan situasi yang kadang tidak mendukung membuat pekerjaan tidak diselesaikan dengan tepat waktu, dalam kondisi tertentu karyawan mempunyai kemampuan untuk dapat menyelesaikan pekerjaanya. Oleh karena itu karyawaan harus dapat memanfaatkan waktu sebaik mungkin agar pekerjaanya seseuai dengan waktu yang telah ditetapkan. 


\section{Kehadiran}

Absensi di PT Perkebunan Nusantara VIII kebun Tambaksari memang masih manual, kehadiran karyawan cukup baik hal ini menunjukan profesional dalam bekerja. Waktu kerja bagaian lapangan dimulai lebih diawal dibanding dengan karyawan kantor, untuk penyelesaian kerja setiap afdeling memang berbeda-beda.

Menurut Mathis dalam Filanisa (2017:19) kehadiran merupakan memenuhi atau tidaknya standar nilai kehadiran sesuai dengan aturan dan tata tertib yang berlaku dalam organisasi. Namun untuk setiap harinya bagi beberapa responden bahwa Pekerjaan yang menumpuk terkadang membuat tidak tenang, sehingga karyawan memilih untuk menyelesaikan pekerjaanya pada hari itu juga, sehingga tidak setuju bahwa responden selalu datang dan pulang sesuai dengan peraturan yang ada. Ada saatnya ketika pekerjaan menumpuk pulang kerja terkadang tidak sesuai dengan peraturan yang ada. Kehadiran karyawan sangat penting berkaitan dengan proses pekerjaan, Karyawan mempunyai cara tersendiri dalam bekerja, tidak dipungkiri bahwa masih ada kayawan yang telat atau pulang lebih dulu, Apapun absensi baik itu manual maupun menggunakan alat, kehadiran merupakan tergantung dari tanggung jawab dari masingmasing karyawan. tentu perusahaan mengharapakan bahwa karyawan dapat bekerja sesuai dengan prosedur yang telah ditentukan oleh perusahaan.

\section{E. Bekerja sama}

Responden dalam penelitian merupakan anggota kelompok yang berada pada setiap afdeling baik itu bagian kantor ataupun lapangan. Segala bentuk laporan hasil kerja di lapangan diberikan kepada TU setiap afdeling, sehingga diperlukan kerja sama baik itu karyawan bagian lapangan ataupun bagian TU. Tidak bisa dipungkiri bahwa tidak semua karyawan dapat memahami apa yang menjadi tugasnya dalam menyelesaikan perkerjaan bersama-sama. Hal ini sesuai dengan apa yang dikemukakan oleh Kusama dan Susanto bahwa Kerjasama dalam perusahaan akan tercipta ketika semua individu yang ada dapat memahami tugas yang dikerjakan.

Karyawan tentu harus memahami apa yang menjadi tugasnya, hal ini untuk memudahkan dalam bekerja sama. karyawan tentu dapat bekerja sama sesuai dengan kemampuanya masing-masing. Memang tidak bisa dipungkiri bahwa tidak semua karyawan dapat memberikan kontribusi yang baik dalam bekerja sama, namun dengan adanya kerja sama ini karyawan tentu dapat saling membantu serta memudahakan dalam proses perkerjaan.

\section{F. Komunikasi}

Pada penelitian ini kepala afdeling memberikan rencana berkaitan dengan pekerjaan yang akan dilakukan selalu TU memberikan tugas serta informasi untuk disampaikan kepada setiap mandor, dan hasil dari lapangan diberikan kepada Tu. Hal ini sesuai dengan apa yang dikemukakan Oleh Wijaya (2017:110) bahwa komunikasi merupakan sarana yang dimana orang mengklarifikasi harapan mereka dan mengkoordinasi pekerjaan, yang memungkinkan mereka mencapai tujuan organisasi dengan lebih efesien dan efektif. Komunikasi harus selalu dilakukan untuk dapat 
memudahkan dalam proses pekerja, karyawan bagian kantor tentu harus dapat berkomunikasi dengan bagian lapangan terkait dengan laporan lapangan. Tentu dengan berkomunikasi kinerja akan meningktkan. Hal ini sesuai dengan yang dikemukakan oleh Sopiah dalam Wijaya (2017:81) Untuk berkinerja baik sebagai anggota tim, individuindividu harus mampu berkomunikasi secara terbuka dan jujur. Komunikasi sangatlah penting dalam perusahaan, setiap karyawan tentu mempunyai cara tersendiri untuk dapat menyampaikan permasalahan serta harapan yang berkaitan dengan pekerjaan tentu. dengan adanya komunikasi tentu proses dalam bekerja akan lebih memudah, sehingga kinerja karyawan akan meningkat.

\section{G. Peran serta}

Pada peneitian ini mendiskusikan permasalahan dalam bekerja merupakan hal yang biasa dilakukan, karyawan tentu dapat mendiskusikan permasalahan yang terjadi dengan rekan kerja atau dengan atasan, namun tidak semua karyawan terlibat secara langsung dalam mendiskusikan permasalahan yang terjadi.

Hasil uji hipotesis menunjukan bahwa stres kerja memiliki pengaruh positif dan signifikan terhadap kinerja karyawan PT Perkebunan Nusantara VIII Kebun Tambaksari. Hasil penelitian ini mendukung hasil penelitian terdahulu, Riandy (2016) yang menyatakan dalam penelitianya bahwa adanya pengaruh positif dan signifikan antara stres kerja terhadap kinerja karyawan.

Hal ini pun sesuai dengan penelitian yang dilakukan oleh Tri wartono pada tahun 2017 yang menyatakan dalam penelitiannya bahwa terdapat pengaruh yang signifikan yang sangat atau positif antara stres kerja terhadap kinerja karyawan Stres kerja memang merupakan satu hal yang tidak hindari, setiap karyawan tentu pernah merasakan stres dalam bekerja, stres yang dirasakan memiliki gejala serta respons yang berbeda-beda, begitu juga dengan tahapan stres.

Namun hasil penelitian ini tidak mendukung penelitian sebelumnya yang dilakukan oleh Natalya Rachel dkk (2018) bahwa stres kerja berpengaruh negatif dan signifikan terhadap kinerja karyawan pada kantor pengeolaan IT Center Manado. Tentu tidak selamanya bahwa stres kerja dapat berpengaruh positif, hal ini tergantung dari bagaimana karyawan tersebut dapat mengelola stres kerja dalam menghadapi pekerjaanya, ketika karyawan dapat mengelola dengan baik sehingga hal itu dapat meningkatkan kinerja karyawanya.tetapi sebalikya ketika karyawan dapat mengeolanya tentu hal ini akan berdampak negatif.

\section{Kesimpulan}

Penelitian ini bertujuan untuk mengetahui serta menganalisis stres kerja, kinerja karyawan dan pengaruh stres kerja terhadap kinerja karyawan PT Perkebunan Nusantara VIII Kebun Tambaksari. Dari identifikasi masalah yang diajukan serta berdasarkan analisis data yang telah dilakukan serta pembahasaan yang telah dikemukakan maka diperoleh kesimpulan sebagai berikut

1. Berdasarkan hasil penelitian, dapat diambil kesimpulan bahwa tanggapan hasil responden mengenai stres kerja berkategori sedang. Stres kerja yang dialami 
karyawan berada pada tahap pertama, stres kerja ini juga bernilai positif. Namun Positif dan negatif mengenai stres kerja tergantung dari individunya. Bagaimana individu tersebut dapat menilai sesuatu sebagai stres atau bukan, tentu stres kerja akan mempengaruhi dalam proses pelaksanaan pekerjaan, tetapi ketika individu dapat mengelola stres tersebut maka stres kerja akan bernilai positif namun ketika stres yang dialami melebihi kemampuan individu tersebut maka akan benilai negatif.

2. Berdasarkan hasil penelitian, dapat diambil kesimpulan bahwa kinerja karyawan PT Perkebunan Nusantara VIII Kebun Tambaksari berada dikategori sedang. Karyawan merasa bahwa jumlah hasil kerja telah memenuhi tuntutan perusahaan serta melaksanakan waktu dengan tidak menunda-nunda. Hal ini membuktikan bahwa kinerja karyawan PT Perkebunan Nusantara VIII Kebun Tambaksari sudah baik.

3. Berdasarkan hasil analisis serta pembahasan stres kerja memiliki pengaruh positif dan siginifikan terhadap kinerja karyawan. Hal ini dibuktikan dengan uji determinasi bahwa pengaruh stres kerja terhadap kinerja karywan PT Perkebunan Nusantara VIII Kebun Tambaksari sebesar 0,356atau 35,6\%. Artinya terdapat pengaruh stres kerja sebesar 35,6\% mempengaruhi variabel kinerja karyawan sedangkan sisanya 64,4 \% dipengaruhi oleh faktor yang tidak diteliti dalam penelitian ini.

\section{Referensi}

Ananda dan Sunuharyo. 2018. Jurnal. Pengaruh karakteristik individu dan karakteristik pekerjaan terhadap kinerja karyawan dengan variabel mediator motivasi kerja karyawan.(Studi Pada Karyawan PT Petrokimia Gresik) Vol. 58 No. 1 Mei

Asih,2015.Pengaruh keperibadian dan stres kerja terhadap kinerja pegawai Sekolah Tinggi Penerbangan Indonesia (STPI) Curug Tanggerang. Vol.10 No.1 Februari 2015-47

Aslihah. 2012. Pengaruh Stres Kerja terhadap kinerja karyawan di Koperasi Syari' ah Binama semarang: Universitas Islam Negeri Walisongo Semarang

Burhan. 2005. Metodologi Penelitian Kuantitatif.Jakarta:kencana prenada Media Grup

Filanisa, Ira .2017. pengaruh stres kerja dan jam kerja shifting terhadap kinerja karyawan PT. Infomedia Sokusi Humanika Bandung: Universitas Widyatama

Indasari, Meithiana.2017.Kepuasaan dan Kinerja Karyawan.Sidoarjo:Indo Mediapusaka

Jayanti Rika \& Maulidina.2015.Jurnal. Pengaruh stres kerja terhadap kinerja Pegawai Pada PDAM Titranasi Cabang SEI Agul Medan. Vol 04, No 01,2015-62

Komarudin.2018.Jurnal. Hubungan stres kerja dengan Kinerja Pegawai Pada PT Herona Express kantor pusat Pamulang: Vol.6,No 1,Januari 2018-73

Mu'ah,Masram.2017. Manajemen Sumber Daya Manusia Profesional, Sidoarjo : Zifatama Publisher

Mangkunegara Anwar prabu, 2014. Evaluasi kinerja SDM, Bandung : PT Refika Aditama Marjuni sukmawati,2015.Manajemen Sumber daya manusia, Makassar :CV.Sah Media 


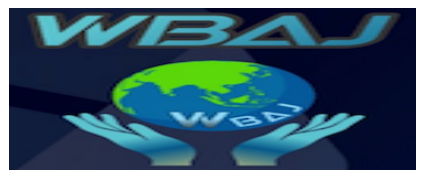

Volume 2 Issue 1, Juni 2020

https://ejournal.unsub.ac.id/index.php/bisnis

Priyonto,2014. Konsep Manajemen Stres, Yogyakarta: Nuha medika

Riandy. 2016. Pengaruh stres kerja terhadap kinerja karyawan Pada PT Borneo Laboratorium inspeksi dan surveyor di samarinada vol.4 No 4-1059

Rahsel,Yoeyong. 2016. Pengaruh ilkim kerja terhadap kinerja pegawai administrasi pusat Universitas Padajajaran Bandung (studi pada bagaian Admistrasi Umum Unpad) vol.2 No 1 Januari 2016

Wartono,Tri.2017. Pengaruh Stres Kerja Terhadap Kinerja Karyawan. Studi Pada Karyawan Majalah Mother and Baby, Vol 4

Sugiyono.2016. Metode Penelitian Administrasi Bandung: Alfabeta

Wijaya,Candra.2017. Perilaku Organisasi. Medan. Lembaga Peduli Pengembangan Pendidikan Indonesia (LPPPI)

Wijono,Sutarto.2010.Psikologi Industri dan Organisasi. Jakarta. Prenadamedia

Grup

Wijono,Sutarto.2018. Kepemimpinan dalam presepktif organisasi.Jakarta Prenadamedia Grup 